\title{
Refuge
}

Canada's Journal on Refugees

revue canadienne sur les réfugiés

\section{Belonging and Transnational Refugee Settlement: Unsettling the Everyday and the Extraordinary, by Jay Marlowe}

\section{Georgina Ramsay}

Volume 34, Number 2, 2018

URI: https://id.erudit.org/iderudit/1055586ar

DOI: https://doi.org/10.7202/1055586ar

See table of contents

Publisher(s)

Centre for Refugee Studies, York University

ISSN

0229-5113 (print)

1920-7336 (digital)

Explore this journal

Cite this review

Ramsay, G. (2018). Review of [Belonging and Transnational Refugee Settlement:

Unsettling the Everyday and the Extraordinary, by Jay Marlowe]. Refuge, 34(2),

151-153. https://doi.org/10.7202/1055586ar

Copyright (c) Refuge: Canada’s Journal on Refugees, 2018

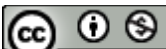

This document is protected by copyright law. Use of the services of Erudit (including reproduction) is subject to its terms and conditions, which can be viewed online.

https://apropos.erudit.org/en/users/policy-on-use/ 
sur l'expérience américaine pour concevoir la «solution du Pacifique».

Ghezelbash démontre que le transfert de politiques s'est effectué dans le même sens en ce qui concerne le traitement extraterritorial des demandes d'asile. Aux ÉtatsUnis, cette pratique a débuté par le triage en mer des demandeurs d’asile arrivés par voie maritime. La base navale de la baie de Guantanamo a ensuite servi de site extraterritorial pour le traitement des demandes. Lauteur explique que la «solution du Pacifique» australienne, qui prévoit le transfert à Nauru et en Papouasie-Nouvelle-Guinée des demandeurs d'asile arrivés par bateau, a beaucoup emprunté aux politiques américaines. Dans les deux cas, l'objectif était de reléguer les demandeurs d'asile à l'extérieur du territoire national et hors de la portée du droit domestique.

Un chapitre entier est consacré à une analyse de la légalité des mesures à l'étude en vertu du droit international. Ghezelbash estime qu'il ne fait aucun doute que les mesures mises en oeuvre en Australie et aux États-Unis violent de nombreux principes de droit international, y compris ceux établis dans le Pacte international relatif aux droits civils et politiques et la Convention relative au statut des réfugiés. La position australienne et américaine voulant que les violations du droit international se produisant à l'extérieur de leur territoire nentraînent pas leur responsabilité étatique est mal fondée : en vertu du droit international, le "contrôle effectif» d'un territoire entraîne la responsabilité étatique, et non la souveraineté.

$\mathrm{Au}$ dernier chapitre, l'auteur examine le succès juridique des transferts à l'étude. Il conclut que les mesures transférées ont résisté dans une large mesure à de nombreuses contestations judiciaires dans les deux pays. Cela est étonnant, compte tenu des différences importantes entre les systèmes juridiques australien et américain sur le plan des droits fondamentaux et de l'incorporation du droit international. Au final, le succès juridique des transferts est dû au fait que les tribunaux domestiques des deux pays considèrent l'immigration, et l'immigration irrégulière en particulier, comme faisant exception à l'application du droit ordinaire.

Dans son chapitre final, l'auteur examine également les conséquences politiques des mesures restreignant le droit des demandeurs d'asile. Son constat est inquiétant : l'interdépendance compétitive des États en matière de contrôle des frontières mène au non-respect répété des normes de droit international. Non seulement ces États perdent l'autorité morale d'insister sur le respect du droit international, mais le régime de protection des droits des réfugiés en entier s'en trouve compromis. Ghezelbash prévient que si l'Europe suit l'exemple de l'Australie et des États-Unis, le régime international des réfugiés risque de subir une «blessure mortelle».

On se trouve, comme l'écrit Ghezelbash, dans une période charnière. Alors que la crise mondiale des réfugiés ne cesse de croître, et que le populisme gagne du terrain partout à travers le monde, on a raison de craindre que les mesures de contrôle des frontières ne continuent de s'accentuer. Force est de constater que, depuis la parution de ce livre, de nouvelles mesures ont été mises en place. Citons comme exemple la directive du procureur général des États-Unis selon laquelle la violence domestique ne constitue pas un fondement suffisant pour recevoir lasile, et la politique américaine qui a mené à la détention et à la séparation de leurs parents de milliers d'enfants. Il semblerait que le nivellement par le bas s'accélère. L’ouvrage de Ghezelbash vaut certainement la peine dêtre lu, car il offre des outils originaux pour comprendre les processus qui mènent à la diffusion de politiques en matière de réfugiés dans un monde de plus en plus interdépendant.

Pierre-André Thériault est un fellow à la Faculté de droit de l'Université Dalhousie et candidat au doctorat en droit à la Faculté de droit Osgoode de l'Université York. Il peut être rejoint à patheriault@gmail.com.

\section{Belonging and Transnational Refugee Settlement: Unsettling the Everyday and the Extraordinary n}

Jay Marlowe

New York: Routledge, 2017, 180 pp.

$\mathrm{H}$ ow can refugee settlement be conceptualized and implemented in ways that foster long-term belonging and meaningful participation in civic life for resettled refugees? Such is the question at the core of Belonging and Transnational Refugee Settlement: Unsettling the Everyday and the Extraordinary. Departing from the emphasis on integration that is prevalent in forced migration and settlement literature, Marlowe advances the concept of belonging as a lens through which to examine refugee settlement. Over six chapters, Marlowe examines refugee 
settlement experiences across diverse international settings using case study data, qualitative interviews, and focus groups. Marlowe challenges conventional assumptions about refugees, and highlights how transcending a singular focus on the extraordinary elements of refugee lives and focusing instead on the everyday can reveal transnational and contested dynamics of refugee settlement, with implications for professional practice.

At a time when resettlement programs in numerous countries are being challenged, Marlowe provides refreshing insight into the possibilities of refugee settlement. The use of case studies from different global contexts ensures its appeal to diverse audiences. Marlowe argues that bringing the everyday dynamics of refugees' lives to the fore of research, public representations, political dialogs, and professional work with refugees is a way to challenge the dominant narratives of victimization, pathologization, and deficiency that situate refugees as abstract problems rather than actual people who lead complex lives.

A central focus of the book is recognizing the transnational dynamics of refugee settlement, which is typically characterized in forced migration literature as a predominantly localized experience. Although only around 1 per cent of refugees globally are resettled annually, examining their settlement experiences through a transnational lens reveals that the lives of the other 99 per cent who often remain within insecure, protracted displacement are significantly affected by those who are resettled: making settlement itself a crucial site of interest for understanding forced migration. Turning attention to the transnational aspects of settlement is a key contribution of the book.

Belonging is the theoretical lens applied to various case studies throughout this book. In scholarly work, belonging can often be applied in vague and uncritical ways, but Marlowe avoids this by identifying three aspects that need to be taken into account when considering how (and whether) people experience belonging in contexts of refugee settlement: social locations; identifications and emotional attachments; and ethical and political value systems. Marlowe notes the important distinction between a society that invites refugees to settle there and a society that welcomes them; between a society that tolerates the presence of refugees and a society that fosters the active participation of refugees.

This critical turn towards belonging allows the experiences of refugees themselves to inform and direct how settlement is evaluated and understood, rather than the more extrinsic and externally determined markers that are typically applied to them through integration discourses. Marlowe identifies aspects of settlement that significantly affect how resettled refugees experience belonging but have otherwise been treated as peripheral in forced migration literature, including exclusionary access to education and employment. That settlement itself can confront resettled refugees with experiences of social and economic exclusion that can be just as traumatizing as displacement is an important point that is often overlooked in forced migration scholarship.

But such musings on belonging are not simply conceptual questions. Chapters 3, 4, and 5 cover trauma, disaster, and professional practice, respectively. Marlowe shows how examining those aspects of refugee settlement experiences through the lens of belonging can foster new ways of supporting refugees to become meaningful participants in their local societies and active members of their transnational networks.

The call to shift from pathologizing refugees through assumptions of trauma by focusing on their individual and collective narratives of everyday experience is not necessarily a new focus of forced migration literature, but it is nonetheless usefully reiterated here. The focus on disasters is a new and much welcomed contribution. By showing how resettled refugees bring unique vulnerabilities and capacities to disaster responses, Marlowe brings attention to the crucial role that forced migration may play in future disasters. Finally, the focus on professional practice is a key strength of the book, which widens its appeal to diverse audiences who work with refugees, particularly in the health and social services. The rights-focused approach set out by Marlowe, which encompasses consideration of the availability, accessibility, acceptability, and adaptability of rights to refugees, is an important contribution. So often refugee policy analyses finish after recognition that particular rights are put in place for refugees, with little consideration of how (or if) these rights are implemented. Within refugee settlement, Marlowe shows that this distinction is significant and suggests that resettlement does not automatically provide refugees with access to cultural, social, and economic rights and freedoms: rather, these must be recognized and promoted at levels of professional practice, political advocacy, and civic life.

Although this book covers many important aspects of settlement, there is scope to consider further dynamics that affect refugees in which resettlement is being challenged and delegitimized. New regimes of securitization can be considered in which resettled refugees may become targets of intensified governance. And the risk of economic exploitation that is embedded in some refugee programs can be recognized: for example in the United States, where policy has long required refugees to secure self-reliant livelihoods within ninety days of arrival, meaning that they are often funnelled into poorly paid menial work with little scope for economic mobility and social inclusion. In addition, although gender dynamics are mentioned briefly throughout the book, there is scope to further explore how everyday dynamics of settlement that Marlowe pointed out reflect 
gendered differences, particularly in shifting livelihood responsibilities, more expansive educational opportunities, and new cultural landscapes.

Overall, Belonging and Transnational Refugee Settlement should be applauded for emphasizing the need to recognize the complexity of refugee lives, and to rethink the dominant assumptions that so often render refugees through singular frames of victimhood. With its accessible theoretical frameworks and diverse case study analyses, Belonging and Transnational Refugee Settlement is highly recommended for undergraduates, graduate students, and practitioners who are interested in refugee settlement from fields of migration studies, sociology, social work, health, policy, and other applied fields.

Georgina Ramsay is an assistant professor of anthropology at University of Delaware and can be reached at gramsay@udel .edu.

\section{Elusive Jannah: The Somali Diaspora and Borderless Muslim Identity \\ $\sim$ \\ Cawo M. Abdi \\ Minneapolis: University of Minnesota Press, 2015, 289 pp.}

I n Elusive Jannah: The Somali Diaspora and Borderless Muslim Identity, Cawo Abdi gives a nuanced account of the lives of the Somali diaspora in three key locations: the United Arab Emirates (UAE), South Africa, and the United States. The book is based on three years of rigorous ethnographic enquiry and meticulous documentation, including 162 interviews and ten focus groups with members of the Somali diaspora. Abdi, herself a Somali-born academic, who arrived in Canada as an asylum seeker, acknowledges the resourcefulness of her positionality in navigating Somali communities with whose culture and predicament she could identify. The book contributes detailed new knowledge and ways of thinking to the refugee and migration literature. Throughout, the book engages with identity, belonging, residency, and integration. A Muslim identity is continually interrogated and juxtaposed with locally encountered identities.

The publication of Abdi's work coincides with the escalation of migration discourses as a priority in foreign policy debates on obligations to asylum seekers and refugees from failed states, such as Somalia. Within these discussions, the implications for the receiving community in national resource sharing (such as welfare) and cultural assimilation or integration have taken centre stage. The three research sites show the importance of "place" in how integration experiences unfold.

The book is divided into six chapters: an introduction, a conclusion, and four chapters. The book launches with a chapter entitled, "The Genesis of Contemporary Somali Migrations." Here Abdi describes the Somali experience and seamlessly integrates the role and history of Dadaab (a collective of three refugee camps in northeastern Kenya) as the launch pad into the pursuit of the Jannah (Arabic for paradise). The volume provides intriguing detail about Somalia's history with democracy, dictatorship, violence, and crisis, allowing the reader to understand the breakdown that led to the current era of exodus, as well as previous large population movements, including the exoduses to the UAE in the 1970 s in the wake of Somalia-Ethiopia war.

The first case study is set in the UAE, an absolute monarchy that remains a non-signatory to the 1951 UN Convention on Refugees (among other international human rights documents). Studying Somali experiences in the UAE is significant, because this setting and how it meets its own need for foreign labour while simultaneously circumventing the liberal human rights legal regime is distinctive. Importantly, the UAE doesn't provide for pathways to citizenship for migrants. Somali interviewees frame the UAE as an easy country to navigate. They described benefiting from the favouritism the Emirati showed them due to a shared Arab identity. In a county made up of 80 per cent foreign labour, with no integration system, this hierarchy of differences works in Somalis' favour. This part of the book provides rare insight into the realities and politics of migration outside a liberal democracy setting.

The second case study is South Africa, a democratic republic in its infancy. This setting conjures questions of migration policy in a post-apartheid context of pervasive racism and extreme inequality. The case studies of Somalis residing in Johannesburg and Cape Town are interwoven with the realities of transforming South Africa and the tightrope the state walks in attempting to simultaneously meet 